\title{
PENINGKATAN KUALITAS LIMBAH DETERJEN DENGAN FITOREMEDIASI MENGGUNAKAN DIVERSITAS HIDROMAKROFITA INDONESIA
}

Oleh:

Dyah Ayu Fajarianingtyas, Catur Retnaningdyah, Endang Arisoesilaningsih. Jurusan Biologi, Fakultas MIPA, Universitas Brawijaya Malang, 2006.

\begin{abstract}
ABSTRAK
Penelitian ini bertujuan menentukan (1) Efektivitas hidromakrofita polikultur dalam media tanah dibandingkan tanpa tanah pada fitoremediasi, (2) Perubahan pH, suhu, konduktivitas dan kadar deterjen pada variasi proses remediasi tersebut. Hidromakrofita yang digunakan yaitu polikultur (Alternanthera sessilis, Commelina nudiflora, $C$. brevifolius, Eclipta prostrata, Ipomoea aquatica, Ludwigia alternifolia, L. ascendens dan Marsilea crenata). Penelitian menggunakan RAL dengan lima kali ulangan. Kualitas limbah deterjen yang diamati adalah $\mathrm{pH}$, suhu, konduktivitas dan kadar deterjen. Hasil penelitian menunjukkan bahwa hidromakrofita polikultur yang tumbuh dalam media tanah, sedikit lebih efektif menurunkan limbah deterjen (96,05\%) dari kadar deterjen awal 22,88 $\mathrm{mg} / \mathrm{L}$ selama 15 hari dalam fitoremediasi dibandingkan dalam media hidroponik (92,72\%).

Hidromakrofita polikultur hidup di tanah tergenang limbah deterjen mampu menurunkan nilai konduktivitas dari 2,35 mS/cm menjadi $1,16 \mathrm{mS} / \mathrm{cm}$ selama 15 hari. Akan tetapi konduktivitas pada media hidroponik berfluktuasi. Pada fitoremediasi selama tujuh hari, pH meningkat dan suhu berfluktuasi tanpa terpengaruh oleh media tanam atau kehadiran hidromakrofita.
\end{abstract}

Kata kunci: Fitoremediasi, limbah deterjen, hidromakrofita Indonesia

\section{PENDAHULUAN}

Perkembangan industrialisasi yang tidak berwawasan lingkungan mendorong lajunya tingkat pencemaran baik di air, tanah, maupun udara sehingga merugikan bagi banyak kehidupan. Sesuai dengan Abel (1989) sumber utama pencemaran bahan organik adalah sampah domestik dan sisa olahan industri. Pengaliran busa deterjen ke Laut Jawa akan membahayakan kehidupan ikan sampai ke Laut Banda (Sastrawijaya, 2000). Menurut Anonimus (2004) deterjen merupakan salah satu limbah domestik yang merupakan penyebab utama pencemaran air. Air selokan dan badan air yang tercemar dan melimpas ke daratan menyebabkan pencemaran yang terjadi di perairan juga berdampak pada pencemaran di daratan. Penggunaan deterjen secara intensif akan berdampak pada pencemaran lingkungan perairan. Hal ini didukung dari banyaknya pilihan produk deterjen yang diinformasikan melalui iklan dan takaran penggunaan deterjen yang kurang tepat (Anonimus, 2004). Menurut Sudifanto (1993) penggantian campuran soda kaustik dari minyak nabati atau minyak hewani pada sabun dengan senyawa kimiawi dari minyak bumi pada deterjen menyebabkan deterjen bersifat rekalsitran yakni sangat sulit diuraikan oleh mikroorganisme. Dengan demikian, dampak negatif dari deterjen semakin terasa karena dapat mencemari lingkungan.

Menurut Sastrawijaya (2000), banyaknya bahan pencemaran dalam perairan akan mengurangi spesies yang ada dan pada umumnya akan meningkatkan populasi jenis yang tahan terhadap kondisi perairan tersebut. Sedangkan menurut Pine (1978), deterjen dalam perairan sangat berbahaya bagi organisme perairan meskipun konsentrasinya kecil. Respon biota terhadap deterjen di antaranya adalah kematian, bioakumulasi, perubahan 
tingkah laku, perubahan daya tahan, tingkat reproduksi dan distribusi (Jeffries dan Mills, 1990; Connel dan Miller, 1995). Hal ini terbukti dari hasil penelitian Huda (2001) bahwa surfaktan deterjen (LAS dan ABS) menyebabkan terjadi penambahan ruang antar sel pada subepidermis kulit Planaria (Dugesia trigina) mulai dari konsentrasi $0,25 \mathrm{mg} / \mathrm{l}$ LAS dan ABS. Selain itu, penelitian Indrianah (2001) menjelaskan bahwa adanya perlakuan surfaktan ABS konsentrasi 1,4 mg/l dan LAS konsentrasi $0,9 \mathrm{mg} / \mathrm{l}$ dapat menghambat mobilitas Melanoides granifera. Dengan demikian, pengaruh limbah deterjen pada biota perairan dapat tercermin dari perubahan struktur komunitas makroinvertebrata bentos. Sedangkan menurut Perlman (1974) molekul surfaktan deterjen telah diketahui bersifat toksik pada jaringan insang yaitu berupa kerusakan epitel yang disebabkan oleh penurunan tegangan permukaan oleh surfaktan deterjen.

Apabila tingkat pencemaran masih ringan, maka semua komponen ekositem tersebut masih mampu untuk melakukan swa purifikasi secara alami. Akan tetapi apabila tingkat pencemaran melebihi kapasitas swa purifikasinya, maka kualitas ekosistem tersebut akan mengalami penurunan. Hal ini akan memperburuk kualitas air tersebut. Ekosistem yang sudah tidak seimbang tersebut dapat diperbaharui dengan cara memberdayakan organisme-organisme pendegradasi bahan pencemar dan menciptakan kondisi lingkungan yang mendukung kinerjanya. Beberapa penelitian telah dilakukan mengenai peran hidromakrofita dalam mengurangi bahan pencemar di perairan karena hidromakrofita adalah salah satu produsen di perairan yang berpotensi untuk menghasilkan oksigen. Selama ini beragam hidromakrofita Indonesia ataupun eksotik tersebut telah diketahui mampu bertahan hidup dalam kondisi di perairan sawah yang sudah banyak tecemar oleh pestisida. Hal ini terbukti dari penelitian Suharjono dkk. (2000) yang menemukan bahwa Eichorhia crassipes, Hydrilla verticillata dan Ludwigia ascendens dalam waktu 12 hari dengan penutupan $20-30 \%$ mampu menurunkan kadar deterjen dari 0,66-2,83 $\mathrm{mg} / \mathrm{l}$ menjadi 0,02-0,1 mg/l. Beberapa hidromakrofita Indonesia adalah tumbuhan yang toleran terhadap limbah deterjen yang dihasilkan dari "binatu" dengan urutan toleransi sebagai berikut Cyperus brevifolius, Ludwigia alternifolia, Marsilea crenata, Ipomoea aquatica, Eclipta prostrata, L. ascendens, Commelina nudiflora dan Alternanthera sessilis (Hartati dan Arisoesilaningsih, 2005). Tumbuhan tersebut diduga berpotensi sebagai agen fitoremediator limbah deterjen. Tumbuhan tersebut tidak mengalami nekrosis, kelayuan dan kematian setelah ditumbuhkan pada media deterjen.

Berdasarkan hal tersebut maka perlu dilakukan penelitian tentang bagaimana efektivitas diversitas hidromakrofita Indonesia sebagai agen fitoremediasi terhadap kualitas limbah deterjen walaupun masih dalam taraf skala laboratorium. Salah satu teknik yang dapat dipakai adalah fitoremediasi menggunakan diversitas hidromakrofita Indonesia yaitu tumbuhan yang tumbuh lokal maupun hasil naturalisasi di wilayah Indonesia. Mengingat pada penelitian sebelumnya menggunakan tanaman monokultur, eksotik serta pemanfaatan diversitas tanaman dalam jumlah yang relatif sedikit, maka fitoremediasi dengan sistem polikultur perlu dilakukan.

Tujuan penelitian yaitu menentukan efektivitas fitoremediasi limbah deterjen dengan menggunakan hidromakrofita polikultur yang tumbuh dalam media tanah dibandingkan dengan media tanpa tanah serta menentukan perubahan $\mathrm{pH}$, suhu, konduktivitas, dan kadar deterjen pada beberapa variasi proses fitoremediasi.

Manfaat penelitian ini adalah menambah informasi mengenai potensi hidromakrofita sebagai agen 
fitoremediator limbah deterjen, mengembangkan tanaman sebagai agen remediasi limbah dan meningkatkan bioprospecting hidromakrofita sebagai agen biologis yang sekaligus juga dapat mengkonservasi plasma nutfah, memperoleh informasi potensi limbah deterjen sebagai media tumbuh bagi beragam tanaman air untuk selanjutnya hasil penelitian ini diharapkan juga dapat digunakan pemerintah sebagai dasar pertimbangan untuk pengelolaan terhadap ekosistem perairan yang tercemar deterjen dengan teknik ramah lingkungan.

\section{METODE PENELITIAN}

\section{Waktu, Tempat dan Bahan Penelitian}

Penelitian ini dilaksanakan pada bulan Maret 2005 sampai Januari 2006. Hidromakrofita diperoleh dari area persawahan kecamatan Lowokwaru Kota Malang. Aklimatisasi dan perlakuan tanaman dilakukan di rumah kaca Laboratorium Ekologi dan Diversitas Hewan sedangkan analisis deterjen dilakukan di Laboratorium Mikrobiologi dan Laboratorium Fisiologi Tumbuhan Kultur Jaringan dan Mikroteknik Tumbuhan, Jurusan Biologi, Fakultas Matematika dan Ilmu Pengetahuan Alam, Universitas Brawijaya.

Hidromakrofita yang digunakan dalam penelitian ini adalah Alternanthera sessilis, Commelina nudiflora, Cyperus brevifolius, Eclipta prostrata, Ipomoea aquatica, Ludwigia alternifolia, $L$. ascendens dan Marsilea crenata yang diambil dari area persawahan di Kecamatan Ketawang Gede, Kota Malang. Pemilihan sembilan spesies untuk penelitian ini adalah berdasarkan hasil penelitian sebelumnya (Suharjono dkk., 2000; Hartati dan Arisoesilaningsih, 2005). Limbah deterjen komposit diambil dari tiga tempat binatu yaitu di daerah Sumber Sari, Sawojajar dan Ketawang Gede Kota Malang. Penentuan tempat pengambilan deterjen berdasarkan hasil penelitian sebelumnya (Hartati dan Arisoesilaningsih, 2005).

\section{Pengamatan Variasi Media Hidromakrofita Polikultur pada Proses Fitoremediasi Limbah Deterjen}

Akuarium berukuran TxLxH $\mathrm{cm}^{3}$. Dua akuarium T1 diisi tanah setinggi $\pm 3,0 \mathrm{~cm}$ sedangkan dua akuarium T0 tanpa diisi tanah. Akuarium H0 tidak ditumbuhi hidromakrofita sedangkan akuarium H1 ditumbuhi hidromakrofita polikultur. Selanjutnya empat kombinasi perlakuan tersebut diisi air kran setinggi $\pm 5,0 \mathrm{~cm}$ dan diaklimatisasi selama dua minggu dengan masing-masing pengulangan sebanyak lima kali. Setelah proses aklimatisasi berakhir maka air kran diganti dengan limbah deterjen komposit dari tiga binatu sehingga di dapatkan variasi komposisi hidromakrofita sebagai berikut:

T0L1H0 : Akuarium diisi limbah deterjen setinggi $\pm 5,0 \mathrm{~cm}$, tanpa tanah dan tanpa ditumbuhi hidromakrofita.

TOL1H1 : Akuarium diisi limbah deterjen setinggi $\pm 5,0 \mathrm{~cm}$, tanpa tanah dan ditumbuhi hidromarofita.

T1L1H0 : Akuarium diisi limbah deterjen setinggi $\pm 5,0 \mathrm{~cm}$, menggunakan tanah dan tanpa ditumbuhi hidromarofita.

T1L1H1 : Akuarium diisi limbah deterjen setinggi $\pm 5,0 \mathrm{~cm}$, menggunakan tanah dan ditumbuhi hidromarofita.

\section{Pemantauan Kualitas Air Limbah Deterjen}

Karakter limbah deterjen komposit diketahui melalui pengukuran $\mathrm{pH}$, konduktivitas, suhu,dan kadar deterjen. Parameter yang diamati secara periodik setiap dua hari sekali adalah $\mathrm{pH}$, suhu, dan konduktivitas. Kadar deterjen diukur di awal, tengah dan akhir percobaan.

Pengukuran $\mathrm{pH}$ air dilakukan dengan menggunakan $\mathrm{pH}$-meter portabel. Setelah dilakukan proses kalibrasi, pengukuran $\mathrm{pH}$ dilakukan dengan memasukkan probe ke dalam akuarium. Suhu $\left({ }^{\circ} \mathrm{C}\right)$ diukur dengan menggunakan termometer digital. Konduktivitas 
(mS/cm) diukur dengan menggunakan konduktivimeter digital.

Pengukuran kadar deterjen dilakukan dengan menggunakan metode MBAS (Methylene Blue Active Substance) (Clescery et al., 1989). Kandungan kadar deterjen yang diukur berasal dari sampel tanah, air dan tanaman.

Langkah awal yang dilakukan untuk sampel tanah adalah sampel 5 gram ditambah air sebanyak $40 \mathrm{ml}$ tersebut disentrifugasi dengan kecepatan $5000 \mathrm{rpm}$ selama 10 menit, kemudian diambil bagian supernatan sebanyak $2,5 \mathrm{~mL}$ dan diencerkan dengan akuades hingga mencapai $25 \mathrm{~mL}$. Sedangkan untuk sampel tanaman adalah sampel tersebut dihaluskan dengan menggunakan mortar, ditimbang lalu diperas dengan ditambahkan akuades sebanyak $40 \mathrm{~mL}$. Hasil perasan tersebut disentrifugasi diambil supernatan hingga mencapai 25 $\mathrm{mL}$. Pada sampel dari air limbah deterjen diambil sebanyak $25 \mathrm{~mL}$.

Selanjutnya untuk $25 \mathrm{ml}$ supernatan sampel tersebut ditambahkan tiga tetes indikator phenolpthalin. Warna merah dihilangkan dengan penambahan satu tetes $\mathrm{H}_{2} \mathrm{SO}_{4} 1 \mathrm{~N}$. Selanjutnya sampel ditambah dengan $5 \mathrm{~mL} \quad \mathrm{CHCl}_{3}$ (kloroform) dan $10 \mathrm{~mL}$ methylene blue. Larutan dikocok dengan shaker pada kecepatan $150 \mathrm{rpm}$ selama dua menit dan dipisahkan dalam labu pisah $100 \mathrm{~mL}$. Hasil ekstraksi dicampur pada botol dan ditambah $25 \mathrm{~mL}$ larutan pencuci (wash solution). Campuran tersebut kemudian dikocok dengan menggunakan shaker dengan kecepatan $150 \mathrm{rpm}$ selama dua menit dan dilakukan penyaringan dengan glass wool. Ekstrak diencerkan dengan $\mathrm{CHCl}_{3}$ hingga $25 \mathrm{~mL}$, ditentukan nilai absorbansi menggunakan spektrofotometer UV-VIS pada panjang gelombang $652 \mathrm{~nm}$. Konsentrasi surfaktan diketahui pada kurva standar.

\section{Analisis Data}

Data numerik hasil percobaan ditabulasi dan digambarkan dalam bentuk grafik. Pola degradasi limbah deterjen dalam sistem fitoremediasi digambarkan melalui persamaan regresi antara penurunan kadar deterjen dan konduktivitas limbah deterjen sejalan dengan waktu inkubasi.

Pengaruh

pemberian hidromakrofita, dan waktu pendedahan terhadap berbagai parameter kualitas air diketahui dengan melakukan analisis ragam. Apabila $\mathrm{H} 0$ ditolak pada tingkat signifikansi 0,05 maka analisis dilanjutkan dengan uji Beda Nyata Jujur (BNJ) dengan tingkat kepercayaan 95\%. Analisis data untuk uji Anova dan BNJ dilakukan dengan SPSS for Windows Release 12,0. Potensi hidromakrofita sebagai agen fitoremediasi dapat dilihat dari persentase penurunan kadar deterjen selama waktu pendedahan nyata lebih tinggi daripada kontrol.

\section{HASIL DAN PEMBAHASAN \\ Efektivitas Fitoremediasi Limbah Deterjen Menggunakan Variasi Kultur Hidromakrofita dan Pengenceran}

Selama 15 hari pada proses fitoremediasi hidromakrofita polikultur yang tumbuh dalam media tanah (T1L1H1) lebih besar menurunkan kadar deterjen sebesar 96,05\% dibandingkan dalam media tanpa tanah (TOL1H1) sebesar 92,72\% (Tabel 1). Hal ini juga didukung bahwa kadar deterjen yang terkandung dalam tanah sebesar 10,19 $\mathrm{mg}$ /gram pada $\mathrm{H} 0$ (remediasi) dan 10,14 $\mathrm{mg} /$ gram pada $\mathrm{H} 1$ (fitoremediasi) dengan kadar deterjen limbah awal sebesar 22,88 $\mathrm{mg} / \mathrm{L}$.

Penurunan kadar deterjen pada remediasi tanpa hidromakrofita dalam media hidroponik $(93,77 \%)$ maupun dengan tanah $(93,20 \%)$ tidak terpaut jauh. Fenomena ini mengindikasikan bahwa mikroba di limbah deterjen berperan besar dalam proses fitoremediasi. Selain itu juga dapat ditunjukkan bahwa tanpa kehadiran hidromakrofita atau tanah, pada dasarnya ekosistem perairan mempunyai mekanisme homeostasis untuk menjaga keseimbangannya (Alam, 1996). Hal ini 
juga dibuktikan pada bahwa kadar deterjen yang terkandung dalam tanaman hanya sebesar 0,61 mg/gram dengan kadar deterjen awal sebesar 22,88 $\mathrm{mg} / \mathrm{L}$. Kehadiran limbah deterjen justru meningkatkan produktivitas pucuk dan akar Ipomoea aquatica (kangkung) dibandingkan kontrol, akan tetapi rasio keduanya akan meningkat atau menurun tergantung media fitoremediasi dan spesies tanaman (Waluyo dkk., 2005). Pengurangan kadar deterjen di lingkungan perairan disebabkan terutama oleh adanya degradasi mikoorganisme (golongan bakteri). Oleh karena itu, perlu dilakukan penelitian lanjutan untuk menemukan spesies hidromakrofita yang lebih produktif dan efektif dalam fitoremediasi limbah deterjen.

Tabel 1. Penurunan kadar deterjen dalam fitoremediasi polikultur dengan media tanah dan tanpa tanah

\begin{tabular}{|c|c|c|c|c|c|c|}
\hline \multirow{2}{*}{ Perlakuan } & \multicolumn{3}{|c|}{$\begin{array}{c}\text { Kadar deterjen (mg/L) pada hari } \\
\text { ke- }\end{array}$} & \multicolumn{3}{|c|}{ Penurunan deterjen (\%) } \\
\cline { 2 - 7 } & 3 & 6 & 15 & 3 & 6 & 15 \\
\hline T0L1H0 & 14,95 & 4,36 & 1,43 & 34,65 & 80,96 & 93,77 \\
T0L1H1 & 10,26 & 6,00 & 1,67 & 55,18 & 73,77 & 92,72 \\
T1L1H0 & 10,06 & 6,56 & 1,56 & 56,05 & 71,32 & 93,20 \\
T1L1H1 & 7,88 & 3,61 & 0,90 & 65,53 & 84,21 & 96,05 \\
\hline
\end{tabular}

Keterangan: Kadar deterjen awal sebesar 22, $88 \mathrm{mg} / \mathrm{L}$; T0=tanpa tanah; $\mathrm{T} 1=$ dengan $\operatorname{tanah} ; \mathrm{H} 0=$ tanpa hidromakrofita; H1=hidromakrofita polikultur; L1=limbah deterjen komposit

Pada Gambar 1 ditunjukkan baik dengan media tanah maupun media tanpa tanah terjadi kecenderungan penurunan kadar deterjen dari semua perlakuan. Pola penurunan kadar deterjen mengikuti persamaan regresi polinomial dengan tingkat signifikansi 95\%. Menurut Atlas dan Bartha (1981) faktor yang mempengaruhi degradasi surfaktan antara lain kebutuhan nutrisi yang tersedia bagi bakteri untuk menghasilkan energi dan meningkatkan pertumbuhan, suhu yang berperan dalam meningkatkan aktivitas bakteri, dan $\mathrm{pH}$ yang berperan dalam mempertahankan kestabilan metabolisme dan keberadaan enzim agar tidak terganggu. Proses degradasi secara aerob akan mempengaruhi jumlah oksigen yang terlarut di dalam air.

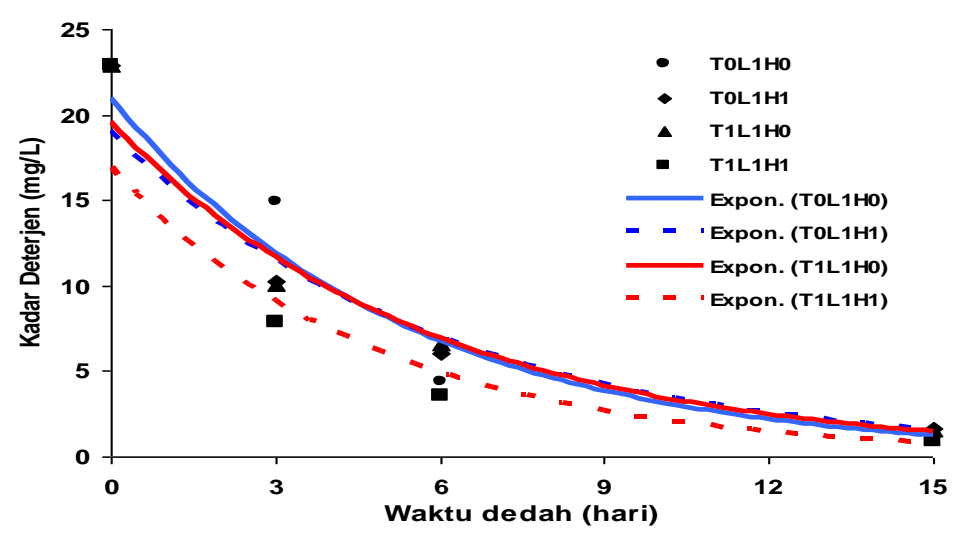

Gambar 1. Model penurunan kadar deterjen dalam proses bioremediasi

Keterangan: $\mathrm{T} 0=$ tanpa tanah; $\mathrm{T} 1=$ dengan tanah; $\mathrm{H} 0=$ tanpa hidromakrofita; $\mathrm{H} 1=$ hidromakrofita polikultur; $\mathrm{L} 1=$ limbah deterjen komposit 
Peningkatan kualitas limbah deterjen

Tanaman mampu menurunkan konduktivitas karena hidromakrofita menyerap mineral yang ada di media (di tanah dan kolom air) melalui akar dan akar adventif. Hasil degradasi deterjen tidak terakumulasi namun dimanfaatkan untuk pertumbuhan tanaman. Hasil penelitian Waluyo dkk. (2005) menunjukkan bahwa produktivitas pucuk dan akar hidromakrofita lebih tinggi jika ditanam secara polikultur dalam media berisi tanah tergenang limbah deterjen dibandingkan dengan sistem hidroponik.

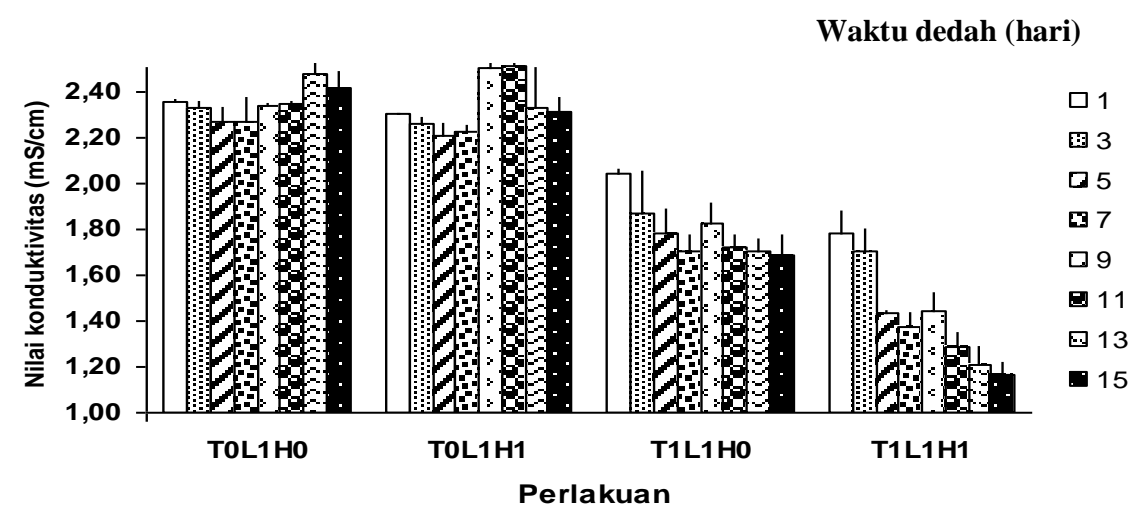

Gambar 2. Perubahan konduktivitas $(\mathrm{mS} / \mathrm{cm})$ pada fitoremediasi limbah deterjen selama 15 hari

Keterangan: T0=tanpa tanah; $\mathrm{T} 1=$ dengan tanah; H0=Tanpa Hidromakrofita; H1=Hidromakrofita polikultur; L1=limbah deterjen komposit.

Penurunan konduktivitas diduga karena kondisi perairan yang kurang mengandung elektrolit-elektrolit kuat ataupun konsentrasi garam (salinitas). Hal lain kemungkinan ditunjang dengan keberadaan jenis mikroba yang dapat mengubah senyawa organik (hidrokarbon, etanol, kloroform) maupun anorganik (ammonia, sianida, hidrogen, sulfida, dll) pencemar. Hasil penelitian Harijati dkk. (1994) isolat bakteri Staphylococcus aureus, S. epidermidis, dan Enterobacter gergoviae mampu melakukan aktivitas biodegradasi terhadap limbah deterjen jenis Alkyl Benzene Sulfonat (ABS) $(36,12 \%)$ dan Linier Alkyl Sulfonat (LAS) $(43,08 \%)$. Bahan organik yang terdapat dalam perairan didekomposisi oleh mikroorganisme menjadi senyawasenyawa anorganik. Senyawa anorganik merupakan konduktor kuat dibandingkan dengan senyawa organik (Ginting, 1992). Menurut Brower dan Van Ende (1990) perairan yang tercemar mempunyai nilai konduktivitas yang tinggi, semakin tinggi nilai konduktivitas maka semakin banyak jumlah ion dalam air.

Dalam proses fitoremediasi hingga tujuh hari, nilai $\mathrm{pH}$ meningkat secara nyata pada tingkat kepercayaan $95 \%$. Dari Gambar 3 terlihat bahwa nilai $\mathrm{pH}$ awal sebesar 7,72 mengalami peningkatan mulai dari 7,73 sampai 9,38 selama tujuh hari tanpa terpengaruh oleh media tanam dan kehadiran hidromakrofita. Menurut Sastrawijaya (2000) di dalam air, kadar deterjen dapat menaikkan $\mathrm{pH}$ hingga mencapai 10,5 sampai 11 . Kadar $\mathrm{C}_{2}$ yang rendah dan tingginya kadar oksigen terlarut $\left(\mathrm{O}_{2}\right)$ dalam perairan dapat berakibat peningkatan $\mathrm{pH}$. Hal ini juga dibuktikan dari hasil penelitian Yusuf (1999) pada perlakuan Hydrilla verticillata, nilai $\mathrm{pH}$ cenderung meningkat sejalan dengan waktu hingga hari kedelapan mencapai nilai $\mathrm{pH}=9$.

Secara alamiah $\mathrm{pH}$ perairan dipengaruhi oleh konsentrasi $\mathrm{CO}_{2}$ dan senyawa bersifat asam. Nilai $\mathrm{pH}$ perairan akan meningkat karena berkurangnya $\mathrm{CO}_{2}$, 
proses respirasi yang menghasilkan $\mathrm{CO}_{2}$ menyebabkan $\mathrm{pH}$ perairan akan menjadi menurun. Nilai $\mathrm{pH}$ berperan dalam mempengaruhi toksisitas suatu senyawa kimia dan proses biokimiawi perairan, misalnya proses nitrifikasi akan berakhir jika nilai pH rendah (Effendi, 2003).

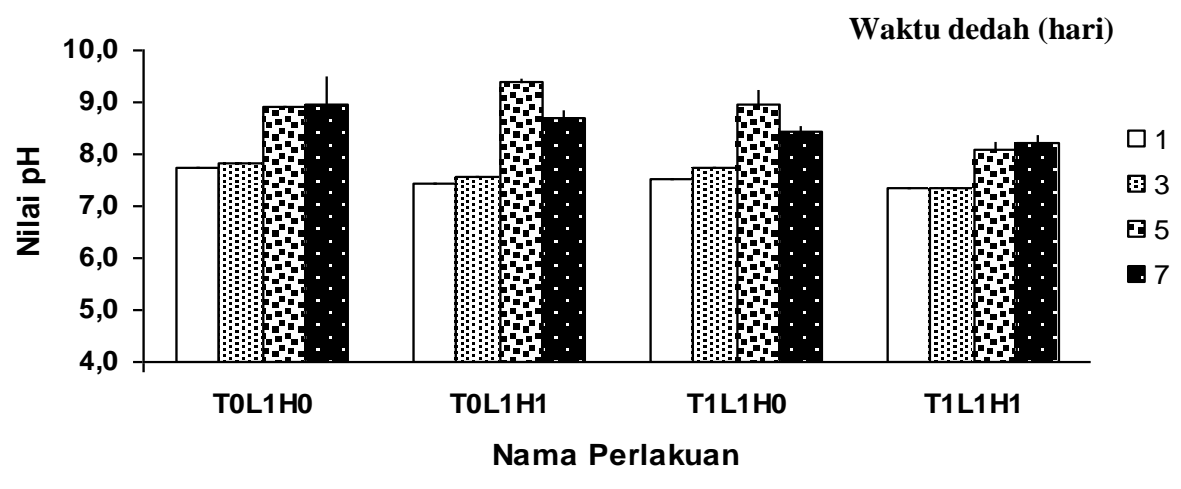

Gambar 3. Perubahan pH pada fitoremediasi limbah deterjen selama tujuh hari

Keterangan: T0=Tanpa tanah; T1=Dengan tanah; H0=Tanpa Hidromakrofita; $\mathrm{H} 1=$ Hidromakrofita polikultur;L1=limbah deterjen komposit.

Dalam proses fitoremediasi hingga tujuh hari, suhu berluktuasi secara nyata pada tingkat kepercayaan 95\%. Dari Gambar 4 terlihat bahwa nilai suhu berfluktuasi mulai dari $23^{\circ} \mathrm{C}$ sampai $26^{\circ} \mathrm{C}$ selama tujuh hari tanpa terpengaruh oleh media tanam dan kehadiran hidromakrofita. Fluktuasi suhu masih dalam kisaran normal. Menurut Ewusie (1990) suhu air di pemukaan tropika biasanya sekitar $25-28^{\circ} \mathrm{C}$. Adanya fluktuasi tersebut kemungkinan dipengaruhi oleh suhu udara. Suhu sangat berpengaruh terhadap proses kimiawi dan biologi di perairan. Kaidah umum menunjukkan bahwa reaksi kimia dan biologi meningkat dua kali lipat untuk setiap kenaikan suhu sebesar $10{ }^{\circ} \mathrm{C}$. Hal ini dapat diartikan bahwa jasad perairan akan menggunakan oksigen terlarut dua kali lebih banyak pada suhu $30^{\circ} \mathrm{C}$ dibandingkan $20 \quad{ }^{0} \mathrm{C}$ (Boyd dan Lichoppler, 1986).
Akan tetapi pada hari ke tujuh, suhu pada semua perlakuan cenderung menurun. Hal ini dipengaruhi adanya cuaca mendung pada saat pengamatan sehingga intensitas cahaya matahari yang diterima oleh perairan sedikit. Suhu perairan banyak dipengaruhi oleh iklim dan kondisi angin, morfologi dasar perairan, topografi dan vegetasi di sekitar perairan serta komponen kimia air. Penurunan suhu disebabkan oleh intensitas cahaya yang diterima oleh air menyebabkan perairan memberikan kemampuan menyimpan energi yang besar dan menghasilkan nilai pemanasan yang lebih lambat dan merata untuk seluruh perairan (Welch dan Lindell, 1980). Ketinggian tempat, hujan, keterbukaan, sumber air, dan suhu sekitar merupakan faktor utama yang mempengaruhi suhu air. Suhu air di malam hari lebih tinggi daripada suhu udara karena adanya kapasitas thermal air yang lebih besar (Whitten et al., 1987). 


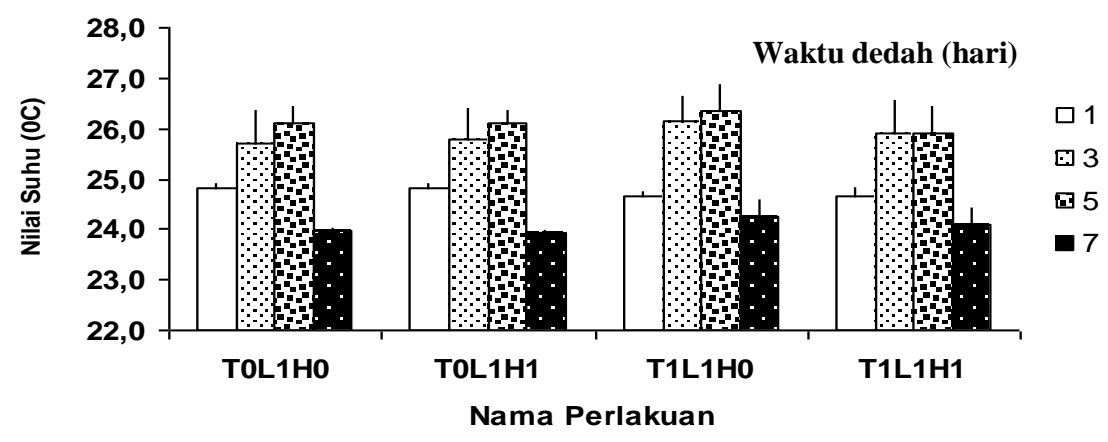

Gambar 4. Perubahan suhu $\left({ }^{0} \mathrm{C}\right)$ pada fitoremediasi limbah deterjen selama tujuh hari Keterangan: $\mathrm{T} 0=$ tanpa tanah; $\mathrm{T} 1=$ dengan tanah; $\mathrm{H} 0=$ tanpa hidromakrofita; $\mathrm{H} 1=$ hidromakrofita polikultur; $\mathrm{L} 1=$ limbah deterjen komposit

\section{PENUTUP}

\section{Kesimpulan}

Hidromakrofita polikultur yang tumbuh dalam media tanah, sedikit lebih efektif menurunkan limbah deterjen $(96,05 \%)$ selama 15 hari dalam fitoremediasi dibandingkan dalam media hidroponik $(92,72 \%)$. Hidromakrofita polikultur hidup di tanah tergenang limbah deterjen mampu menurunkan nilai konduktivitas dari $2,35 \mathrm{mS} / \mathrm{cm}$ menjadi $1,16 \mathrm{mS} / \mathrm{cm}$ selama 15 hari. Akan tetapi konduktivitas air limbah pada media hidroponik berfluktuasi. Pada fitoremediasi selama tujuh hari, $\mathrm{pH}$ meningkat dan suhu berfluktuasi tanpa terpengaruh oleh media tanam atau kehadiran hidromakrofita.

\section{Saran}

Penanaman hidromakrofita secara polikultur dalam media berisi tanah tergenang limbah deterjen menghasilkan produktivitas tanaman lebih tinggi dibandingkan dengan sistem hidroponik. Pada akhir percobaan, kadar deterjen mencapai $0,90 \mathrm{mg} / \mathrm{L}$, akan tetapi kadar deterjen belum memenuhi nilai baku mutu kadar deterjen golongan $\mathrm{C}(0,5 \mathrm{mg} / \mathrm{L})$ maka penelitian perlu dilanjutkan dengan menekankan sistem fitoremediasi yang lebih efektif dan efisien.

\section{DAFTAR PUSTAKA}

Abel, P.D. 1989. Water Pollution Biology. Ellis Horwood Limited Publishers. Chichester.

Alam, R., 1996. Pencemaran dan Pemanfaatan Air di DKI Jakarta, BACA, II: 18-20.

Anonimus. 2004. Pencemaran Air. Diakses dari http:/ www. terranet. or.

$\mathrm{id} /$ tulisan detil. php? $\mathrm{Id}=1566$ pada tanggal 18 November 2004.

Atlas, R.M. and R. Bartha. 1981. Microbial Ecology Fundamentals and Application. Mc Graw Hill Book Company, Inc. New York.

Boyd, C. E. dan F. Lichoppler. 1986. Pengelolaan Kualitas Air Kolam Ikan. Penerjemah Fuad Cholik. Pusat Penelitian dan Pengembangan Perikanan. Jakarta.

Connel, D. W dan G.J. Miller. 1995. Kimia dan Ekotoksikologi Pencemaran. Diterjemahkan dari Chemistry and Ecotoxicology of Pollution, Oleh: Y. Koestoer. Penerbit Universitas Indonesia. Jakarta.

Effendi, H. 2003. Telaah Kualitas Air. Penerbit Kanisius. Yogyakarta.

Ewusie, J. Y. 1990. Pengantar Ekologi Tropika. Terjemahan U, 
Tanawijaya. Penerbit Institut Teknologi Bandung. Bandung.

Ginting, P., 1992. Mencegah dan Mengendalikan Pencemaran Industri. Pustaka Sinar Harapan. Jakarta.

Harijati, N., Suharjono; T. Handayani. 1994. Potensi Komunitas Bakteri Pemecah Deterjen Jenis ABS dan LAS. Jurnal Brawijaya; 100-108. Universitas Brawijaya. Malang.

Hartati, S. dan E. Arisoesilaningsih. 2005. Toleransi Diversitas Hidromakrofita terhadap Limbah Deterjen. Makalah disampaikan dalam Seminar Nasional Basic Science II tanggal 26 Februari 2005 diselenggarakan oleh Fakultas Matematika dan Ilmu Pengetahuan Alam. Universitas Brawijaya. Malang.

Huda, K. 2001. Efek Toksik Surfaktan Deterjen Terhadap Kerusakan Histologis Kulit dan Pharynx Planaria (Dugesia trigina). Skripsi. Fakultas Matematika dan Ilmu Pengetahuan Alam. Universitas Brawijaya. Malang.

Indrianah, Y. 2001. Pengaruh Surfaktan Deterjen (LAS dan ABS) Terhadap Mobilitas Gastropoda (Melanoides granifera) dan (Melanoides tuberculata) yang Ditemukan di Kali Mas Surabaya dan Kali Lekso Wlingi. Skripsi. Fakultas Matematika dan Ilmu Pengetahuan Alam. Universitas Brawijaya. Malang.

Jeffries, M. dan D. Mills. 1990. Freshwater Ecology, Principles and Applications. Belhaven Press. London.

Perlman, D. 1974. Advance in Applied Microbiology. Volume 17. Academic Press. London.

Pine, S.H. 1978. Organic Chemistry. Mc Graw Hill Company. New York.
Sastrawijaya, A.T. 2000. Pencemaran Lingkungan. Penerbit Rineka Cipta. Jakarta.

Sudifanto, A. 1993. Uji Tingkat Biodegradability Deterjen Study Pengaruh Waktu Detensi dan Umur Lumpur terhadap Pengolahan Air Buangan Yang Mengandung Deterjen dengan Activated Sludge. Skripsi. Fakultas Teknik Sipil dan Perencanaan. Institut Teknologi Sepuluh Nopember. Surabaya.

Suharjono, B. Mitakda, M. Yusuf, C. Retnaningdyah, S. Samino dan Prayitno. 2000. Potensi Makrofita Akuatik dalam Meningkatkan Kualitas Air Kali Mas Surabaya. Makalah disampaikan dalam Seminar Nasional Biologi XVI tanggal 25-27 Juli 2000 diselenggarakan oleh Perhimpunan Biologi Indonesia di ITB. Bandung.

Waluyo, G., E. Arisoesilaningsih dan C. Retnaningdyah. 2005. Produktivitas Hidromakrofita Indonesia Yang Tumbuh pada Media Fitoremediasi Limbah Deterjen. Makalah disampaikan dalam Seminar Nasional tanggal 03 Desember 2005 diselenggarakan oleh Fakultas Matematika dan Ilmu Pengetahuan Alam. Universitas Negeri Malang. Malang.

Welch, E.B. dan T. Lindell. 1980. Ecological Effects of Wastewater. Chapman and Hall. London.

Whitten, A.J., M. Mustofa dan G.S. Herder, 1987, Ecology of Sulawesi. Gadjah Mada Press. Yogyakarta.

Yusuf, M. 1999. Potensi Makrofita dari KaliMas Surabaya Untuk Peningkatan Kualitas air. Skripsi. FMIPA. Universitas Brawijaya. Malang. 